\title{
ULTRASTRUCTURAL FINDINGS IN THE MURINE NONCILIATED BRONCHIOLAR CELLS (NCBC) AFTER SUBACUTE INHALATION OF LEAD ACETATE
}

\author{
T. I. FORTOUL ${ }^{1}$, R. C. SALGADO ${ }^{1}$, S. G. MONCADA ${ }^{3}$, I. G. SÁNCHEZ ${ }^{1}$, \\ I. E. LÓPEZ ${ }^{1}$, G. ESPEJEL ${ }^{2}$, N. L. CALDERÓN ${ }^{4}$, L. SALDIVAR ${ }^{2}$ \\ ${ }^{1}$ Cell and Tissue Biology Department, Faculty of Medicine, National Autonomous University of Mexico, \\ ${ }^{2}$ Analytical Chemistry Department, Faculty of Chemistry, \\ National Autonomous University of Mexico, ${ }^{3}$ Hemerobiblioteca J. J. Izquierdo, \\ Faculty of Medicine, National Autonomous University of Mexico, \\ ${ }^{4}$ Department of Avian Production, Faculty of Veterinary Medicine and Animal Science, \\ National Autonomous University of Mexico, Mexico City, Mexico

\section{Received October 16, 1998} \\ Accepted January 14, 1999
}

\section{Abstract}

Fortoul, T. I. , R. C. Salgado, S. G. Moncada, I. G. Sánchez, I. E. López, G. Espejel, N. L. Calderón, L.Saldivar: Ultrastructural Findings in the Murine Nonciliated Bronchiolar Cells (NCBC) after Subacute Inhalation of Lead Acetate. Acta Vet. Brno 1999, 68: 51-55.

Air pollution is an important health problem in some countries. For Mexico City, repeatedly high levels of some metals including lead $(\mathrm{Pb})$ have been reported. Since there is no relevant information, we used an inhalation model to identify the possible lung cell damage after exposure of animals to $\mathrm{Pb}$. We used thirty $\mathrm{CD}-1$ male mice that were inhaling (for 1 hour) aerosolized lead acetate $0.1 \mathrm{M}$, three times per week during two weeks. Mice were sacrificed by cervical dislocation on days $1,3,5,7,10$ and 15 after the last $\mathrm{Pb}$ exposure. Their lungs were fixed by intratracheal instillation of glutaraldehyde. Lung tissue for morphological observation and metal concentration was sampled. In the exposed mice, on days 3 and 5 changes in the nonciliated bronchiolar cells appeared. Whorl-like structures were present in the cell apex. These structures compressed other organelles. On day 5 after the final inhalation, the structures increased in size, and by day 10 they disappeared. After the last inhalation, the metal concentration in the lung tissue continuously decreased until day 7 when no more metal was detected. It was evident that the contact of the NCBC with $\mathrm{Pb}$ produces changes in the morphology of these cells. The metal concentrations in the lung decreased when the exposure ended. This finding supports the assumption that $\mathrm{Pb}$ is not accumulated in lung tissue. As a consequence, the cellular modifications decreased and began their way to morphological recovery.

Nonciliated bronchiolar cell, Clara cell, $\mathrm{Pb}$, inhalation toxicology, bronchiole

Air pollution is a major problem worldwide, particularly in areas such as Mexico City that is considered the most polluted city in the world. In some industrial areas of this city, air concentrations of lead $(\mathrm{Pb})$ ranged from 7.5 to $14.5 \mu \mathrm{g} / \mathrm{m}^{3}$ (three months average) as reported by Albert and B adillo (1992). A report from our laboratory showed increased concentrations of $\mathrm{Pb}$ and other metals in human autopsied lungs when comparing a thirty-year period of the records of people who lived in Mexico City during the 1950's to those of the ones who lived in the same city but in the 1980's (Fortoul 1996). Lead is a component of the 0.1 to $1 \mu \mathrm{m}$ size particles present in the air that enters the lungs by inhalation. Thirty to $50 \%$ of $\mathrm{Pb}$ concentration in this organ is absorbed into blood and from here it is distributed into the whole organism. In situations when the exposure to polluted air is high, the dose by this route could be a great risk resulting in lead intoxication (Tsalev 1985). Only few reports on $\mathrm{Pb}$ toxicity for lung tissue are available, and they mostly focus only on modifications in the function of the alveolar macrophages 
(Zelikoff 1993). Changes in the function of the immune system with decreased antibacterial resistance have also been mentioned (Ehrlich 1980). Almost all written information available is about the effects of this metal on the hematopoietic system, on the kidney or on the nervous system. Lack of information exists as to the effects of inhalation of this metal directly in the lungs and changes in the morphology of cells involved in the detoxification of xenobiotics.

The nonciliated bronchiolar cells (NCBC) are located in the ultimate conducting tubes of the lung; they are rich in cytochrome P-450 monooxigenases and they are the target of a number of xenobiotics including furans, aromatic and halogenated aliphatic hydrocarbons, ozone and others (Kanekal 1990; Serabjit-Singh 1979; Boyd 1977). This cell type could also be a natural target for inhaled lead. We therefore conducted experimental $\mathrm{Pb}$ aerosol exposures using a mouse model to examine the morphologic changes in the nonciliated bronchiolar cells.

\section{Materials and Methods}

Lead acetate in deionized water was tested at concentrations of $0.001 \mathrm{M}, 0.01 \mathrm{M}$ and $0.1 \mathrm{M}$. Light microscopy of the lungs revealed no changes with the first two concentrations, and only slight changes were observed with $0.1 \mathrm{M}$. With these results it was decided to start the experiments using $0.1 \mathrm{M}$ concentration, and a schedule at which the animals would survive.

Mice were selected as a model animal for their evident NCBC (Plopper 1991), and to make sure that the suspected target cells would be produced in such quantity, that the modifications would be easily detected.

For one hour three times a week for two weeks, thirty CD-1 male mice weighing $35 \pm 5 \mathrm{~g}$ inhaled a solution $0.1 \mathrm{M}$ of lead acetate in deionized water. The mice were placed in a plastic chamber - volume of 72.71 - to which an ultrasonic nebulizer (Ultra Neb 99, DeVilbis) was attached. The nebulizer was designed to produce droplets in a 0.5 to $5 \mu \mathrm{m}$ range. A trap for the vapor was located on the opposite side with a solution of sodium bicarbonate to precipitate the remaining $\mathrm{Pb}$. Eighteen mice of the same weight were used as controls, inhaling solely the vehicle with the same schedule. As a second control for acetate, sodium acetate $0.1 \mathrm{M}$ was also inhaled by a group of twelve mice. After each exposure, mice were placed in plastic cages, and they had free access to water and food (Purina Chow) in 12 hour day and light cycles.

After the final inhalation, mice were sacrificed by cervical dislocation on day 1, 3, 5, 7, 10 and 15 according to the local standard legislation for observing animal welfare. Immediately after cervical dislocation, the trachea was exposed and the lungs were fixed by intratracheal instillation with $2.5 \%$ glutaraldehyde in $0.1 \mathrm{M}$ sodium cacodylate buffer, pH 7.4 (470 mmol) at total lung capacity (TLC). After lung expansion, the trachea was tied up and the cardiopulmonary block was removed from the chest cavity. The left lower lobe was ligated and processed for transmission electron microscopy (TEM) following the usual technique in order to identify the terminal bronchiole (Sabatini 1964).

Determination of $\mathrm{Pb}$ in the tissue

We quantified the metal using a modified technique (Fortoul 1996). Results were defined as $\mu \mathrm{g} / \mathrm{g}$ per dry lung tissue (EPA 1994; Keith 1983).

Determination of $\mathrm{Pb}$ concentration in the inhaled air

A filter was positioned at the outlet of the nebulizer, used in the entire experiment, for sixty minutes at a flow rate of $10 \mathrm{l} / \mathrm{min}$. The $400 \mathrm{ml}$ solution used during the entire experiment was nebulized. The filter was removed from the outlet after ten minutes of exposure and then weighed. The treatment of the filter was the same as that of the tissue samples. Using the fluxes dynamic equation $\mathrm{C}=\mathrm{M} / \mathrm{V}$ in which $\mathrm{C}$ was the concentration of $\mathrm{Pb}$ in the filtered air expressed as $\mu \mathrm{g} / \mathrm{m}^{3} ; \mathrm{M}$ corresponded to the total lead mass on the filter, expressed as $\mu \mathrm{g}$. The volume $\mathrm{V}$ in $\mathrm{m}^{3}$ was $\mathrm{V}=\mathrm{Q}^{*} \mathrm{t}$ in which $\mathrm{Q}$ was the flow rate in $1 / \mathrm{min}$ and the time exposure expressed in minutes. Lead concentration in the filter was $7180 \mu \mathrm{g}$. The Volume $(10 \mathrm{l} / \mathrm{min} * 60 \mathrm{~min}$. $)=0.06 \mathrm{~m}^{3}$. Concentration of $\mathrm{Pb}$ in the inhaled air was $11966.6 \mu \mathrm{g} / \mathrm{m}^{3}$.

\section{Results}

\section{Morphological findings}

Controls

The bronchiole was easily identified by the prominence of the nonciliated bronchiolar cells which had a cuboidal form with rounded and rod-shaped mitochondria. Smooth endoplasmic reticulum (SER) and rough endoplasmic reticulum (RER) and some Golgi 
apparatus were identified as well. The apical zone of the nonciliated bronchiolar cells was characterized by few microvilli and few small granules (Plate XIII, Fig. 1).

Animals treated with sodium acetate did not show any morphological changes different from those observed in the controls.

Experimental animals

On day one after the last inhalation, the main changes were observed in the NCBC and some vacuoles were visible in the cytoplasm. There was also an increase in the RER, granules were more electron-dense than those in the controls. On day 3, whorl-like structures were evident, mitochondria were electron-dense, and some small granules were present at the cell apex (Plate XIII, Fig. 2). On day 5, the whorl -like structures increased in size to almost half of the cellular volume, surrounding some cellular organelles. Granules were highly electron-dense and mitochondria with distorted cristae were evident (Plate XIV, Fig. 3a). At higher magnification it was evident that the organelles inside the mentioned structure were two damaged mitochondria (Fig. 3b). Ciliated cells did not show modifications in their structure at all (Fig. 2). Changes in the NCBC persisted until day 7 when the whorllike structures decreased in size. On day 10 these structures were no longer detectable.

\section{Lead concentration in lungs}

In controls and in mice treated with sodium acetate the $\mathrm{Pb}$ levels were under the detection limits. In the experimental animals, on day 1 after the last inhalation the lung concentration of $\mathrm{Pb}$ was the highest and it then continuously decreased from day 5 to day 7 on which no metal was detected as shown in Table 1.

Table 1

$\mathrm{Pb}$ lung concentrations in $\mu \mathrm{g} / \mathrm{g}$ of dry weight. Concentrations after the last day of inhaling $\mathrm{Pb}$ acetate, Sodium Acetate or the vehicle

\begin{tabular}{|l|c|c|c|c|c|c|}
\hline & Day 1 & Day 3 & Day 5 & Day 7 & Day 10 & Day 15 \\
\hline Control & nd $(\mathrm{n}=2)$ & $\mathrm{nd}(\mathrm{n}=2)^{*}$ & $\mathrm{nd}(\mathrm{n}=2)^{*}$ & $\mathrm{nd}(\mathrm{n}=2)$ & $\mathrm{nd}(\mathrm{n}=2)$ & $\mathrm{nd}(\mathrm{n}=2)$ \\
\hline $\mathrm{Pb}$ & $\begin{array}{c}70.6 \pm 6.7 \\
(\mathrm{n}=5)\end{array}$ & $70.1 \pm 4.7(\mathrm{n}=5)^{*}$ & $69.3 \pm 3(\mathrm{n}=5)^{*}$ & $36.4 \pm 3.5(\mathrm{n}=5)^{*}$ & $\mathrm{nd}(\mathrm{n}=5)^{*}$ & $\mathrm{nd}(\mathrm{n}=5)^{*}$ \\
\hline Acetate & $\mathrm{nd}(\mathrm{n}=2)$ & $\mathrm{nd}(\mathrm{n}=2)$ & $\mathrm{nd}(\mathrm{n}=2)$ & $\mathrm{nd}(\mathrm{n}=2)$ & $\mathrm{nd}(\mathrm{n}=2)$ & $\mathrm{nd}(\mathrm{n}=2)$ \\
\hline
\end{tabular}

nd $=$ not detectable

*Student's $t$-test

Days 3, 5 and 7 compared with day 1 were significantly different at $\mathrm{p}<0.005$

\section{Discussion}

The NCBC has the armamentum to metabolize xenobiotics (Kanekal 1990; Serabjit-Singh 1979; Boyd 1977; Ploppler 1991). This cell type is damaged by a variety of chemical compounds, but there are few reports about the lesions of these cells by the inhalation of metals. One report on inhaled cadmium $(\mathrm{Cd})$ referred the damage of this cell type in which a decrease in the number of its granules was evident (Fortoul 1984). This report consisted of a single inhalation of Cd that produced an increase in the excretion of the granules, probably as a nonspecific defense mechanism. In a copperdeficient guinea-pig model some structures similar to those presented in this paper were described; as a result it can be thought that $\mathrm{Pb}$ competes for those places in which $\mathrm{Cu}$ is actively attached producing the morphological changes as those described in this model (Richmond 1993). The exposure to other substances such as isoproterenol, phenobarbital, polychlorobiphenyls, chlorphenteramine and naphthalene are also 
associated with comparable changes (Kitamura 1987). Changes like those reported here were also present in animals exposed to substances defined as drug-induced phospholipidosis (i.e. Gentamicin, chloroquine, chlorpromazine). The changes induced by these substances are by complexing with polar lipids of lysosomal membranes (Che ville 1983).

The increase of the RER amount seemed to be a consequence of the exposure of the cell to $\mathrm{Pb}$, since this structure is not prominent in mice NCBC ( Smith 1979). The increase in the RER is similar to situation reported in neonatal control animals ( $\mathrm{Smith}$ 1974) which could mean an increased protein synthesis and could reflect a high metabolic activity with an increase in microsomal enzyme activities as a direct response to $\mathrm{Pb}$ or as a consequence of the modification of some enzymes which contain other metals which could be inhibited by the presence of $\mathrm{Pb}$ in their structure. The modification in the electron-density of the granules could be attributed to a change in their saturated state (Fawcett 1966).

As reported by others (Morgan 1978; Boudene 1977), the concentration of $\mathrm{Pb}$ in the lungs decreased after the inhalation ceased. The highest concentration, as expected, was found on day 1 after the last inhalation. On the other hand, on days 10 and 15, the concentrations in the lung were under the detection limits similar to the controls. This finding suggests that reduction and elimination of the exposure will also decrease the $\mathrm{Pb}$ lung concentration, and consequently will reduce the concentration of $\mathrm{Pb}$ accessible to the general circulation and to other systems.

$\mathrm{Pb}$ concentrations inhaled by our experimental mice were higher than those reported in the air of Mexico City industrial areas (Albert 1991). In toxicological studies it is possible to use higher concentrations in order to obtain a response. The changes in the NCBC should be taken into account as a notice of the possible damage to some lung cells, other than the alveolar macrophage by inhaled $\mathrm{Pb}$ in those humans highly exposed to this metal. As mentioned before, there is few information in the literature about $\mathrm{Pb}$ damage in the lung. The main objective of this work is to study the lung as an organ that can also be damaged by inhaled $\mathrm{Pb}$ as it was shown by the ultrastructural modifications found.

\section{Ultrastruktura bronchiolárních buněk bez řasinek (NCBC) u myší po subakutní inhalaci acetátu olova}

Znečištění ovzduší je vážným zdravotním problémem v některých zemích. V Mexico City jsou opakovaně naměřeny vysoké koncentrace některých kovů, např. olova. Protože relevatních informací je málo, použili jsme inhalační model na identifikaci možného poškození plicních buněk po expozici zvířat olovu. Použili jsme 30 myších samců CD-1, kteří inhalovali $(1 \mathrm{~h})$ aerosol $0,1 \mathrm{M}$ acetátu olova třikrát týdně (délka pokusu 14 dní). Myši byly utraceny cervikální dislokací v 1., 3., 5., 7., 10. a 15. dnu po poslední inhalaci olova. Jejich plíce byly fixovány intratracheální instilací glutaraldehydu. Vzorky plicní tkáně byly odebrány pro morfologické vyšetření a stanovení koncentrace olova. U myší vystavených působení aerosolu s obsahem olova byly nalezeny změny buněk NCBC na 3. a 5. den. V apikální části buněk byly nalezeny spirálovité struktury, které komprimovaly buněčně organely. Na 5 . den po poslední inhalaci tyto se tyto struktury zvětšovaly, ale do 10. dne vymizely. Po poslední inhalaci koncentrace kovu v plicní tkáni postupně klesala do 7. dne, kdy už žádné zbytky kovu nalezeny nebyly. Kontakt olova s buňkami bez řasinek vyvolal jejich morfologické změny, a koncentrace kovu klesla po ukončení expozice. Tyto údaje podporují předpoklad, že Pb se v plicní tkáni neakumuluje. Buněčné změny vymizely a plicní buňky se začaly regenerovat. 


\section{Acknowledgments}

The authors thank Tomas Cruz, Francisco Pasos, Silvia Antuna, Adrian Rondan and Patricia Bizarro for their technical assistance. This project was supported by Facultad de Medicina, UNAM. A special thank to Dr. E. Rojas and Mahara Valverde for their critical comments to this work and Blanca R. Fortoul and Karina Valencia for editorial review.

\section{References}

ALBERT, L. BADILLO, F. 1991: Environmental lead in Mexico in Review of Environmental Contamination and Toxicology. Vol. 117. Springer Verlag, New York, pp. 136-151

BOUDENE, C., MALET, D., MASSE, R. 1977: Fate of 210Pb inhaled by rats. Toxicol. Appl. Pharmacol. 41: 271-276

BOYD, M. R. 1977: Evidence for the Clara cell as a site of cytochorme P450-dependent mixed-function oxidase activity in lung. Nature 269: 713-715

CHEVILLE, F. N. 1983: Cell Degeneration. In: Cell Pathology, 2nd Ed. Chapter 3. Iowa State University Press, Iowa, pp. 75-129

EHRLICH, R. 1980: Interaction between environmental pollutants and respiratory infections. Environ. Hlth Persp. 35: $89-100$

ENVIRONMENTAL PROTECTION AGENCY (EPA) 1994: Manual for the analysis of water. Environmental Protection Agency, Washington; 84 JO91.

FAWCETT, W. D. 1966: The Cell. Its Organelles and Inclusions. Philadelphia. W. B. Saunders Co., pp. 308-313

FORTOUL ,T. I. 1984: Mecanismos de lesion por algunos contaminantes. Cadmio y su accion patogenica sobre pulmon. (Tesis Maestria) Facultad de Medicina, UNAM, $87 \mathrm{p}$.

FORTOUL, T. I., SALDIVAR, L. O., TOVAR, T. A., SALAZAR, D., CASTILLA, M. E., OLAIZ, F. G. 1996 : Metals in lung tissue from autopsy cases in Mexico City residents. Comparison between cases from the 1950's and the 1980's. Environ. Hlth Persp. 104: 630-632

KANEKAL, S. PLOPPER, G. C. H., MORIND, D., BUCKPITT, A. 1990: Metabolism and cytotoxicity of naphthalene oxide in the isolated perfused mouse lung. J. Pharmacol. Exp. Therapeutics 256: 391-401

KEITH, H. L. 1983: Principles of environmental analysis. Analyt. Chem. 55: 2210-2218

KITAMURA, H., INAYAMA, Y., ITO, T. ,YABANA, M., PIEGORSCH, W. W. , KINISA,W. A. M. 1987: Morphologic alteration of mouse Clara cells induced by glycerol: ultrastructural and morphometric studies. Exp. Lung Res. 12: 281-302

MORGAN, A., HOLMES, A. 1978: The fate of lead in petrol-engine exhaust particulates inhaled by the rat. Environ. Res. 15: 44-56

PLOPPER, G. CH., HYDE, M. D., HUBG, S. H., MENON, C. D. 1991: Clara Cell in The Lung ed. R.G. Crystal, West Chap 3, Raven Press New York, pp. 215-228

RICHMOND, V., CHI, E. Y. 1993: Ultrastructural observations in copper-deficient ginea-pig lung cells. Int. J. Exp. Pathol. 74: 133-143

SABATINI, D. D., MILLER, F., BARNETT, R. T. 1964: Aldehyde fixation for morphological and enzyme histochemical studies with the electron microscope. J. Histochem. Cytochem. 12: 57-71

SERABJIT-SINGH, C. J., NISHIO, S. S., PHILOT, R. M., PLOPPER, G. CH. 1979: The distribution of Cytochrome P-450 monooxigenase in cells of the rabbit lung: An ultrastructural immunocytochemical characterization. Molec. Pharmacol. 33: 279-289

SMITH, M. N., GREENBERG, D., SPJUT, H. J. 1979: The Clara Cell. A comparative ultrastructural study in mammals. Amer. J. Anat. 155: 15-30

SMITH, P., HEATH, D., MOOSAV, I. 1974: The Clara cell. Thorax 29: 147-163

TSALEV, D. L., ZAPRIANOV, Z. K. 1984: Atomic Absorption apectrometry in Occupational and Environmental Health Practice. Vol I. CRC Press. pp.137-150

ZELIKOFF, J. T., PARSONS, E., SCHLESINGER, R. B. 1993: Inhalation of particulate lead oxide disrupts pulmonary macrophage-mediated functions important for host defense and tumor surveillance in the lung. Environ. Res. 62: 207-222 
Plate XIII

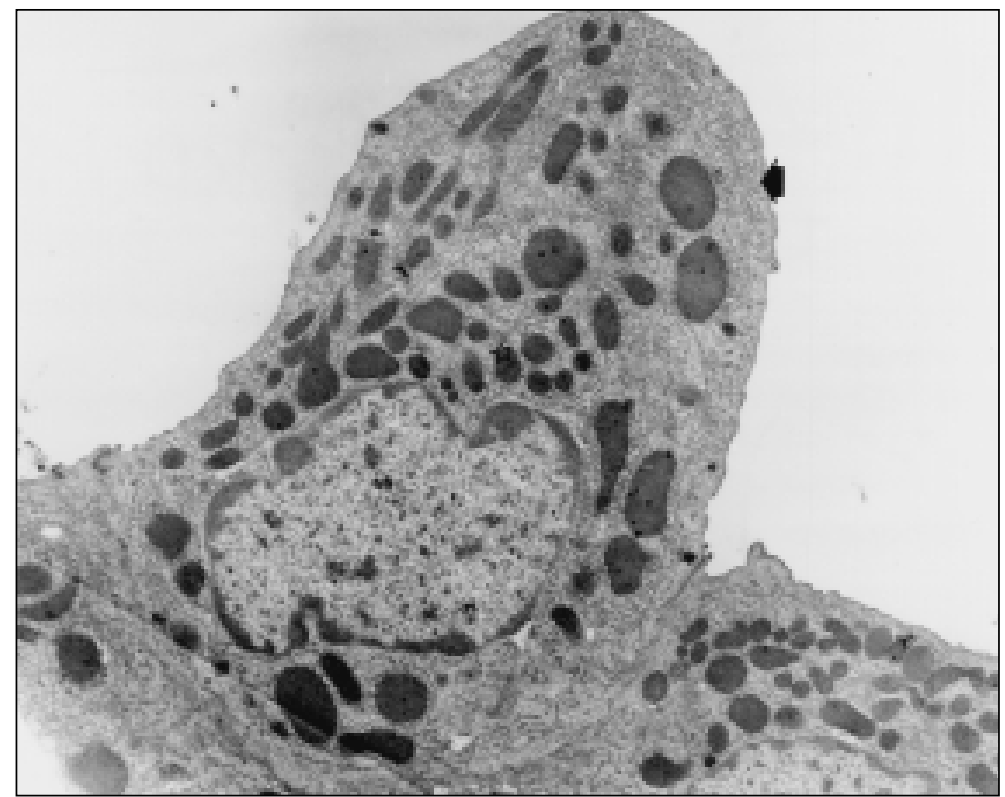

Fig. 1. Control Nonciliated Bronchiolar Cell (NCBC) in which the RER (arrowhead) and some small granules (open star) are identified. Lead Citrate $(10112 \mathrm{X})$.

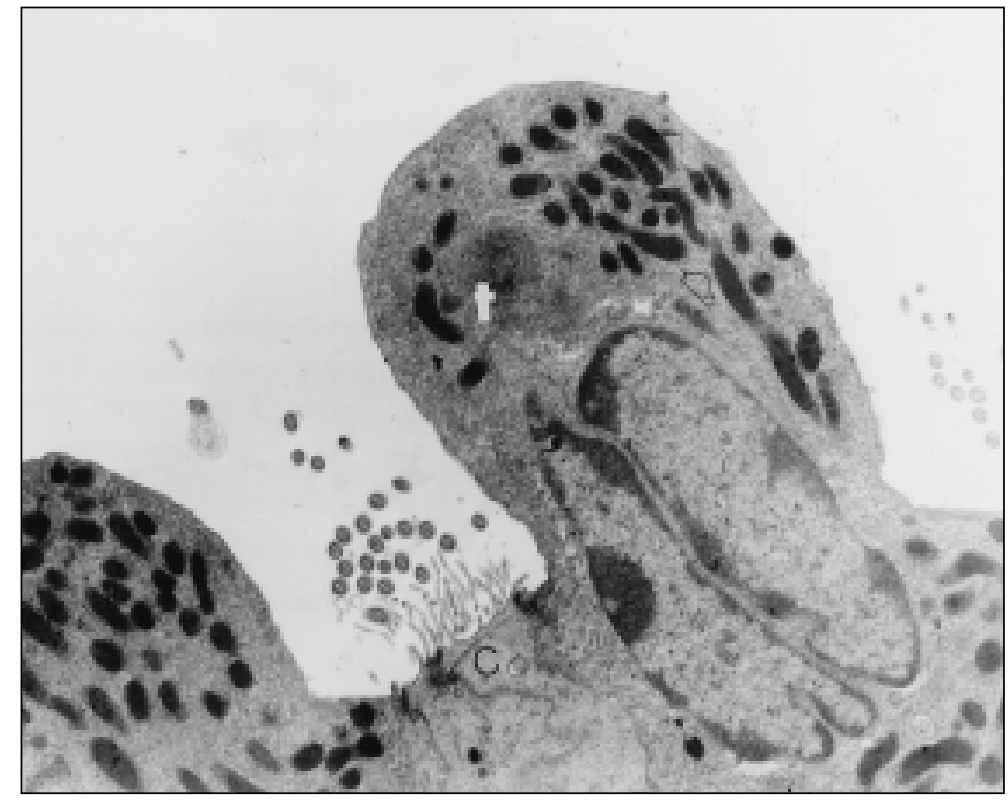

Fig. 2. Three days after the last inhalation the cell was hypertrophic. A whorl-like structure occupies part of the apical portion of the cell volume (t). Also evident mitochondria with cristae disarray and electron-dense matrix (arrowhead). The ciliated cells did not present morphological modifications (c). Lead Citrate (9600 X). 
Plate XIV

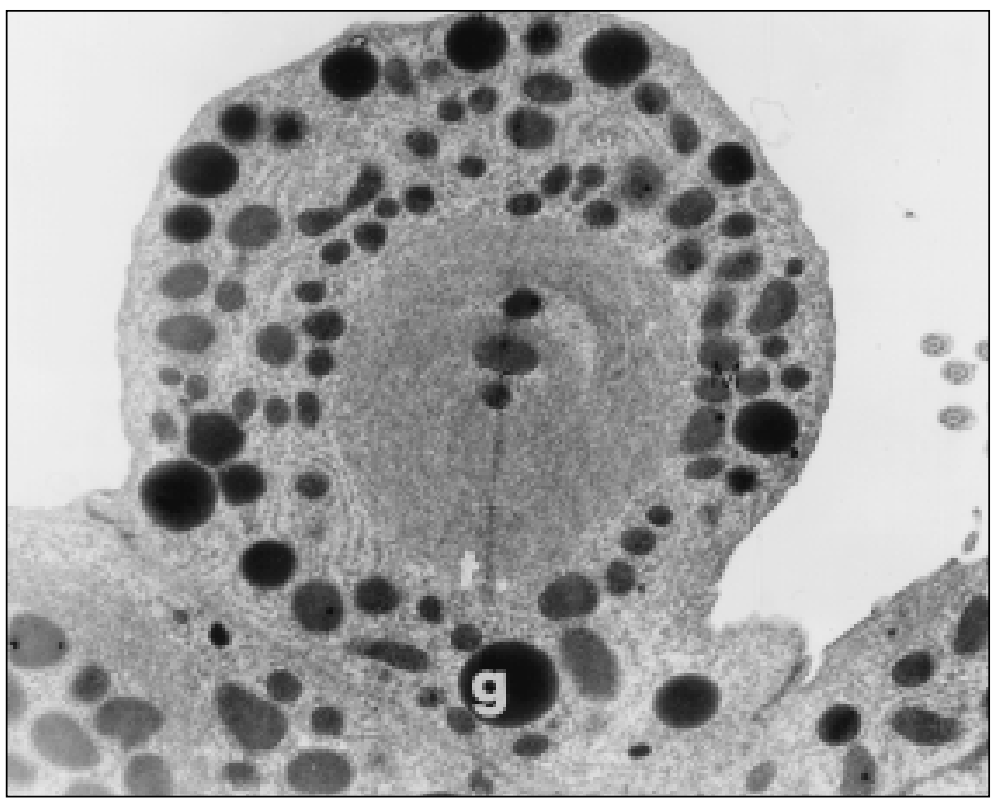

Fig. 3a. On day 5 after the last inhalation the whorl-like structure (t) increased its size. Some dense granules were evident (g), and small altered mitochondria are seen (M). Lead Citrate (11612X).

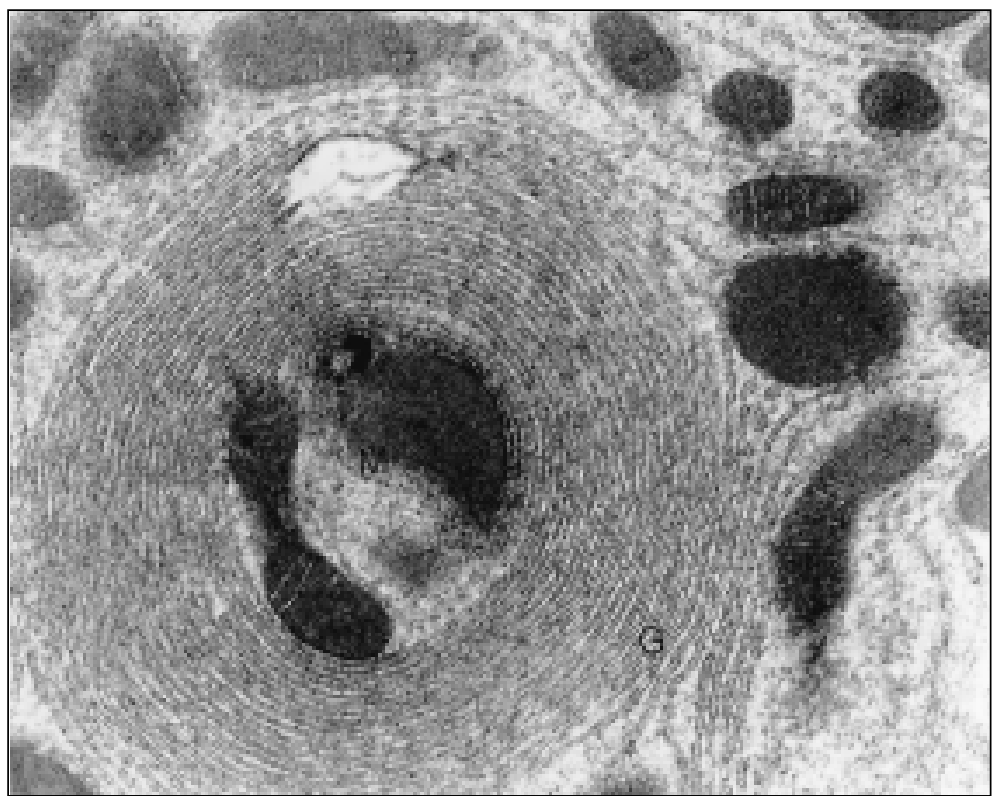

Fig. 3b. At higher magnification the membrane arrays are evident (G). The organelles inside this structure are two altered mitochondria (M). Lead Citrate (42000 X) 